\title{
REGIONAL DISPARITY IN AVAILABILITY OF HEALTH CARE FACILITIES OF BIRBHUM DISTRICT, WEST BENGAL: A SPATIO-TEMPORAL ANALYSIS
}

\author{
Mahuya Sen \\ Assistant Professor of Geography, Birbhum Mahavidyalaya, Suri (West Bangal) India \\ Email: mahuyasen74@gmail.com
}

\begin{abstract}
In search of a healthy prosperous life several attempts have been made throughout the world to develop health care facilities. Since independence health standards in India have improved considerably beside various development processes. The objective of the study is to highlight the development gap of health care facilities of Birbhum District and to find out the health index of the study area to show the disparities among various blocks of the District. The study is made from secondary data collected from the District statistical handbook of 2015. Health index of Birbhum District, 2015 varies from 0.30 to 2.30. Disparities in health care facilities are found among the different blocks of the district and also from rural area to urban area of the district.
\end{abstract}

Key words: Health Care Facility, Development Processes, Health Index, Disparity

\section{Introduction}

According to the Constitution of India, the primary duties of every state are to raise the level of nutrition, the standard of living and to improve public health. The results of better health care facilities are reflected by a better life expectancy, low mortality and low morbidity rate with an intense health care facility. Along with various development processes, health standards in India have improved considerably since Independence. After the Independence the planning commission of India assigned funds for health and to improve health infrastructure, education, research and services; various innovative measures were taken for the purpose. In the first five year plan (1951-56) among various preventive measures, strong steps were taken to start primary health centers at each block headquarters. The government of India formulated a health policy in 1983 to reorient the health delivery system to meet the emerging requirements of the country and also to build up preventive and curative health. Then in 2002, a new health policy was formulated to face the new challenges by augmenting existing health infrastructure so that access to health services across the social and geographical region of the country became more equitable (Misra, R.P.2007). In this policy, involvement of private sector in health services has been given responsibility. With the concerted efforts of the government and other public- private agencies, some of the health indicators in India have experienced impressive growth. 'Longevity has more than doubled since independence, infant mortality rate has fallen, malaria has been controlled, small pox and guinea worm have been completely eradicated and leprosy and polio are nearing elimination'. (Prasad Neeta, February 2010,). Despite these achievements, the health care facilities provided by India to her people are not adequate. When compared to other countries these facilities are amongst the least adequate in the world. Even within India there is marked disparity in the medical facilities of different regions. Some of her states enjoy a progressive health care facility, whereas others are heavily over burdened by an ill-fed, illsheltered unhealthy population. Though some achievements were observed but the difference among the blocks of the district and between rural and urban area has widened. To bridge these gaps a new health policy, the National health policy, 2017 was adopted. This aimed at increasing investment in the primary health sector. It seeks to include everyone in an integrated way to move towards wellness. It aims at achieving universal health coverage and delivering quality health care services to all at a reasonable cost. The present study is an attempt to reveal the block level disparity of health care facility in the district of Birbhum, West Bengal which comprises 
nineteen blocks whose economy is mainly agricultural. To ensure equity of access to all subgroups of population a public healthcare infrastructure across India should be set up in terms of certain norms. According to the Govt. norm there should be one Sub-center (SC) for every 5000 population (3000 population in case of hilly and tribal areas), one Primary Health Centre (PHC) for every 30,000 population and one Community Health Centre (or Rural Hospital) (CHC or $\mathrm{RH}$ ) for every 100,000 to 120,000 population. (Birbhum Human development Report, 922birbhum.pdf)

\section{Objectives}

1. The objective of the present study is to highlight the development in the health system after independence.

2. To find out and analyze the different indicators of the health infrastructure.

3. To show the block level disparity of health care facility in the district of Birbhum, West Bengal.

4. To find out spatial pattern of disparity in the health care facilities through calculating a Health Index in different blocks of Birbhum district.

5. To find out our progress to meet future health care needs.

\section{Location of the Study Area}

The District of Birbhum is located in the western part of the state of West Bengal being surrounded by the districts of Bardhamman on South and South West, Murshidabad in the East and North East along with the State of Jharkhand in North and North West. The district stretches from $23^{\circ} 33^{\prime} 30^{\prime \prime} \mathrm{N}-23^{\circ} 33^{\prime} 45^{\prime \prime} \mathrm{N}$ latitudes and $87^{\circ} 47^{\prime} 00^{\prime \prime} \mathrm{E}-87^{\circ} 49^{\prime} 00^{\prime \prime} \mathrm{E}$ longitudes.(Fig.no. 01)

Figure 01: Map showing the location of West Bengal in India, Birbhum District in West Bengal and Sadar Town in Birbhum District

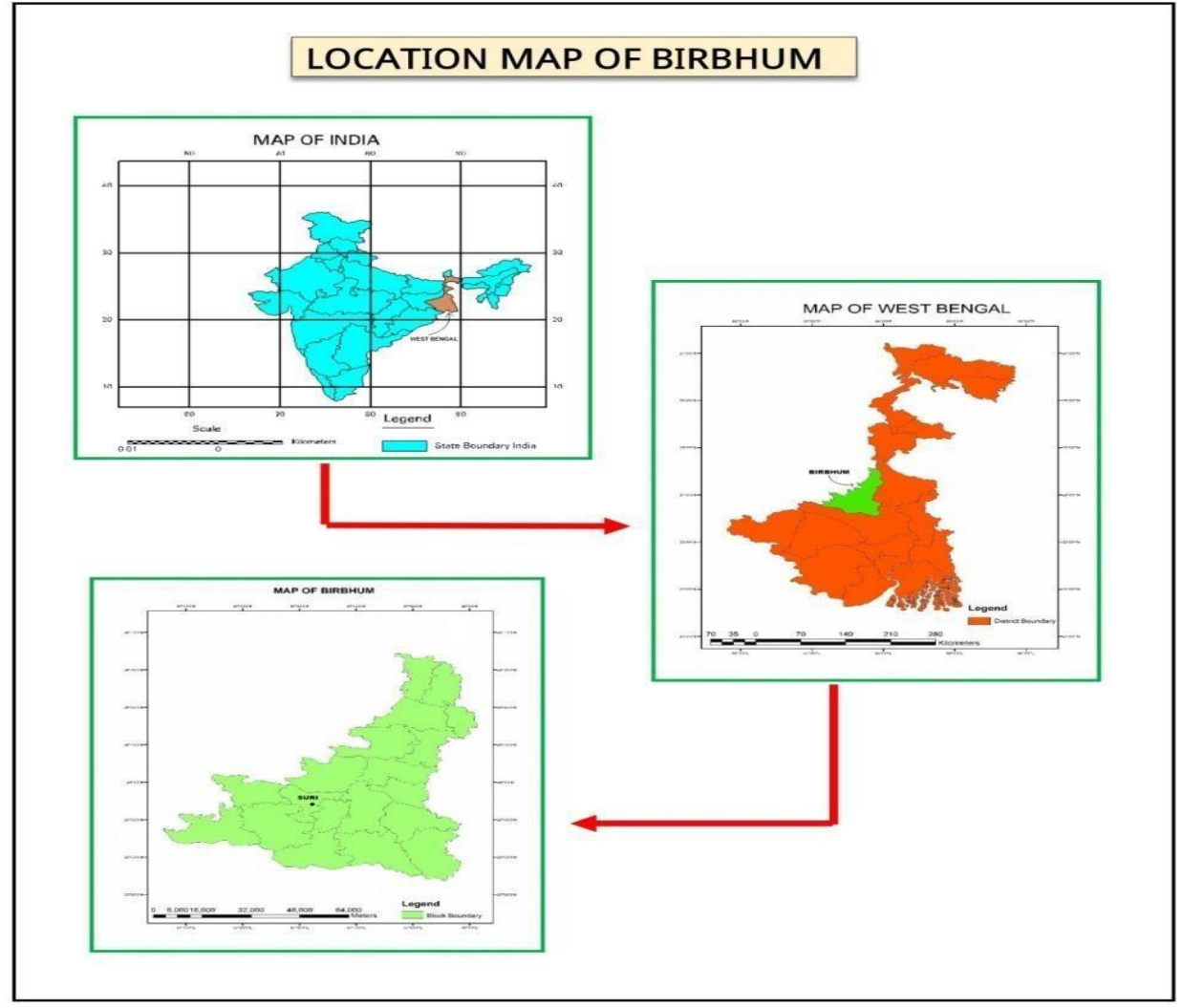


Figure 02: Map showing the three sub-divisions along with respective blocks of Birbhum District

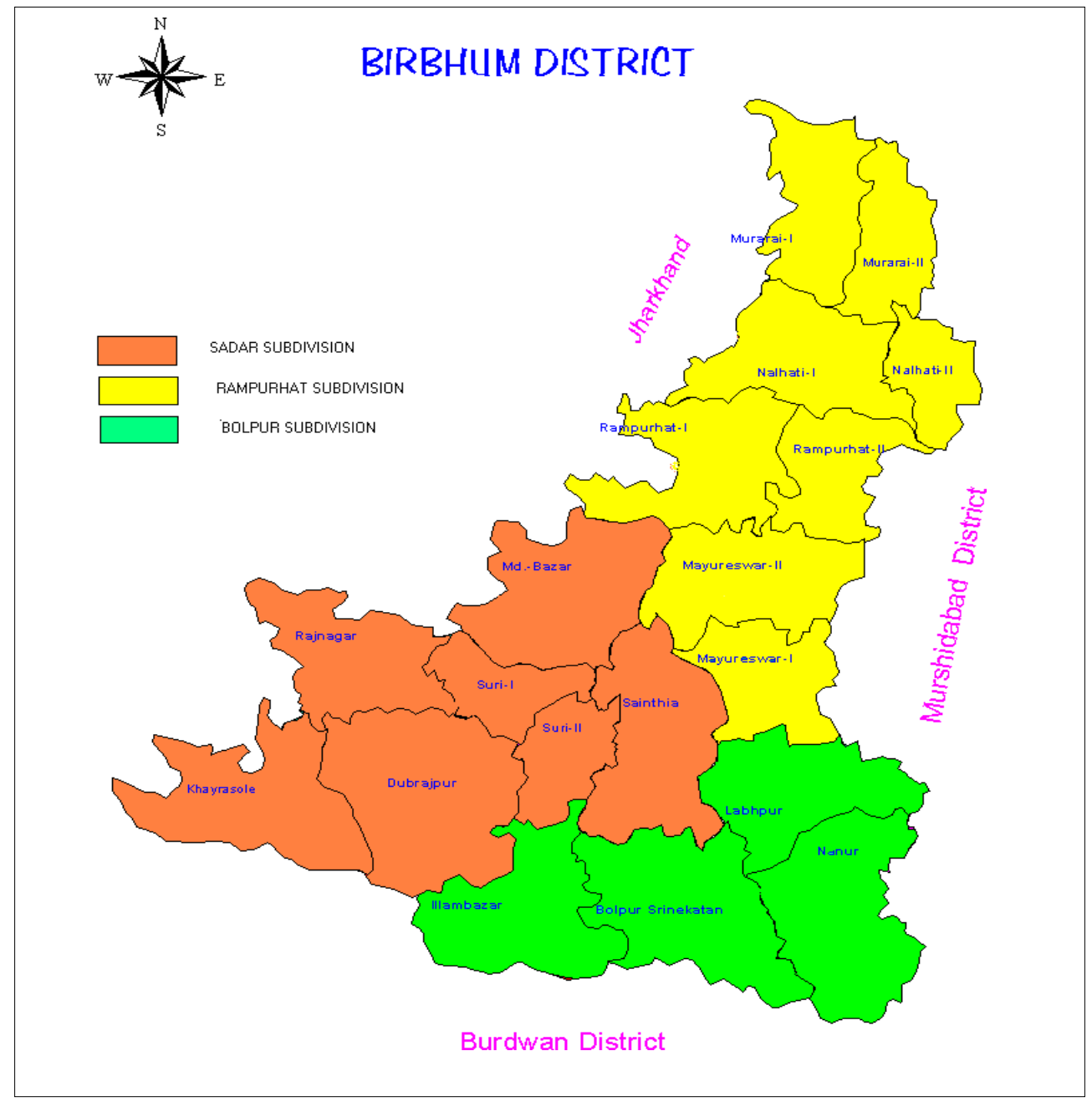

\section{Methodology}

The study is based on block level secondary data available from the District Statistical Handbook of Birbhum, 2011. It is a quantitative analysis. Here four related parameters of health care have been taken into consideration to calculate the Health Index from which to analyze the spatial variation of health care facilities in the study area. The parameters are:

- Health center Density /10 sq. km.,

- Number of beds/1000 populations,

- Number of doctors /1000 populations,

- Number of family welfare centers / 1000 populations

Health Index is calculated on the basis of the above indicators. The Health Index is the simple arithmetical average of the above four parameters. $\mathrm{HI}=1 / 4(1+2+3+4)$. (Roy, Debasish, 2013) Relevant maps are prepared on the basis of health parameters and health indices and analysis is done on them.

\section{Scarcity and Disparity in Health Infrastructures in the Study Area}

Birbhum district has three subdivisions namely Rampurhat, Suri and Bolpur Sub-divisions. The population density varies significantly across the different blocks of the Birbhum district. The blocks in the Rampurhat have the highest population density and the highest aggregate population in the district in comparison with the blocks of the other two sub divisions. But in Rampurhat the physical infrastructure of public health care institutions and health care personnel appear to be substantially insufficient compared with the health care resources supplied to the less populated blocks in the district. According to 2011 data there are 838 
hospital beds and 72 doctors in Rampur hat, where as there are 1543 hospital beds and 82 doctors positioned in Suri Sadar $s$ which has the second highest aggregate population but the lowest population density in the district. Because of these unequal distributions of health care institutions the quality of health care services is below standard. Since population and the total number of health care institutions vary widely across different blocks of the district, the ratio between the population and the number of health care institutions is an indicator to analyze block level disparity in health care infrastructure.

Each block of the district should be served by more than 5 PHCs under the existing national norms instead of the present average per block, which is just above 3 per block. In regional terms, the largest shortfall in the number of PHCs is observed in the populous Nalhati-I block followed by Murarai-I in Rampur hat and Bolpur-Sriniketan and Nanoor blocks in Bolpur sub-division. Nalhati-I block requires 5 additional PHCs and other aforesaid blocks require another 4 PHCs under the existing norm. On the other hand, the corresponding gaps are among the lowest in Mayureshwar-II, Md. Bazar, Sainthia, Rajnagar, Suri-II and Labhpur. Each of these blocks requires one additional PHC following the norm. It is observed from fig. no. 3 that the population density is highest in the northern most blocks namely Muraroi 1 \& 2 and northeastern blocks namely Nalhati 2, Rampurhat 2 and followed by the south eastern blocks such as Mayureswar 2 and Labpur. The lowest population density is found in the western most blocks namely Rajnagar, Khoyrasole and Dubrajpur.

Figure 03: Map showing population density of Birbhum District, 2011

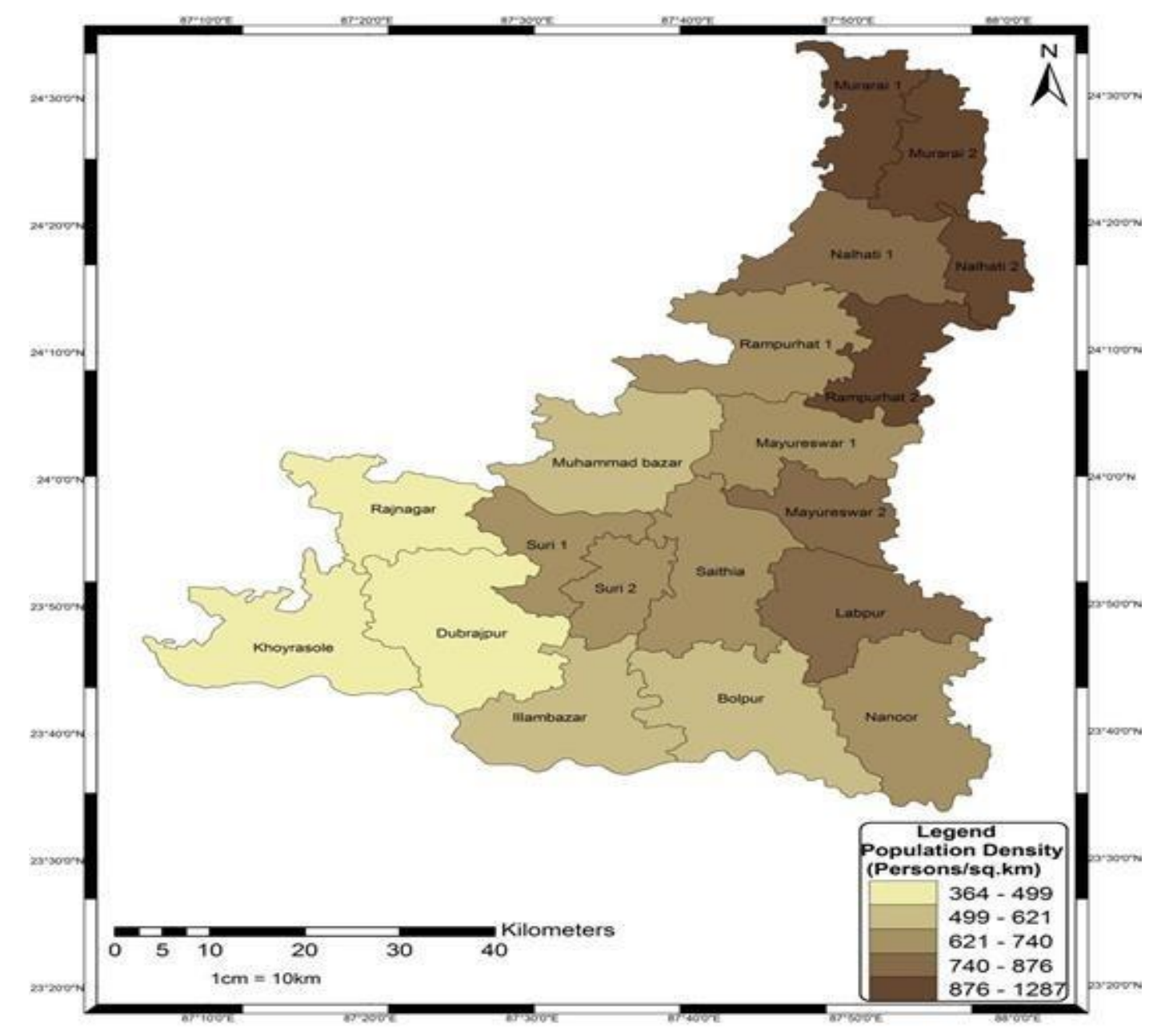


Figure 04: Distribution and number of Beds and Doctors, Birbhum District, 2011

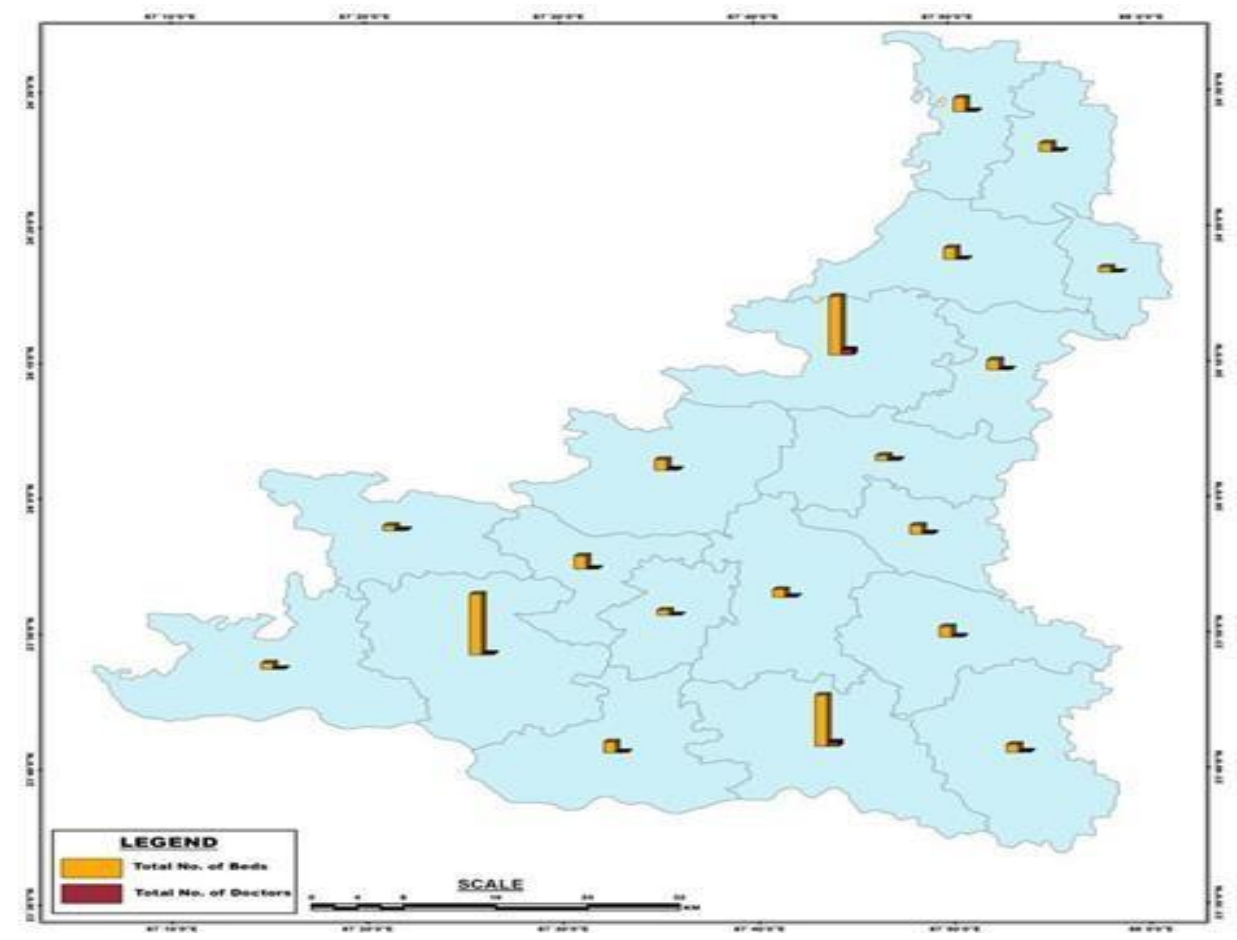

Spatial distribution of number of beds and doctors of the study area are found from the fig. no. 4. The number of doctors and beds are very scanty in most of the blocks of the district. But in three blocks namely Rampurhat I, Dubrajpur and Bolpur- Sriniketan total number of beds are more in number. Obviously Birbhum needs more doctors and beds to raise its doctorpopulation ratio to meet up the huge population pressure.

Figure 05: Health Index of Bibhum District, 2015

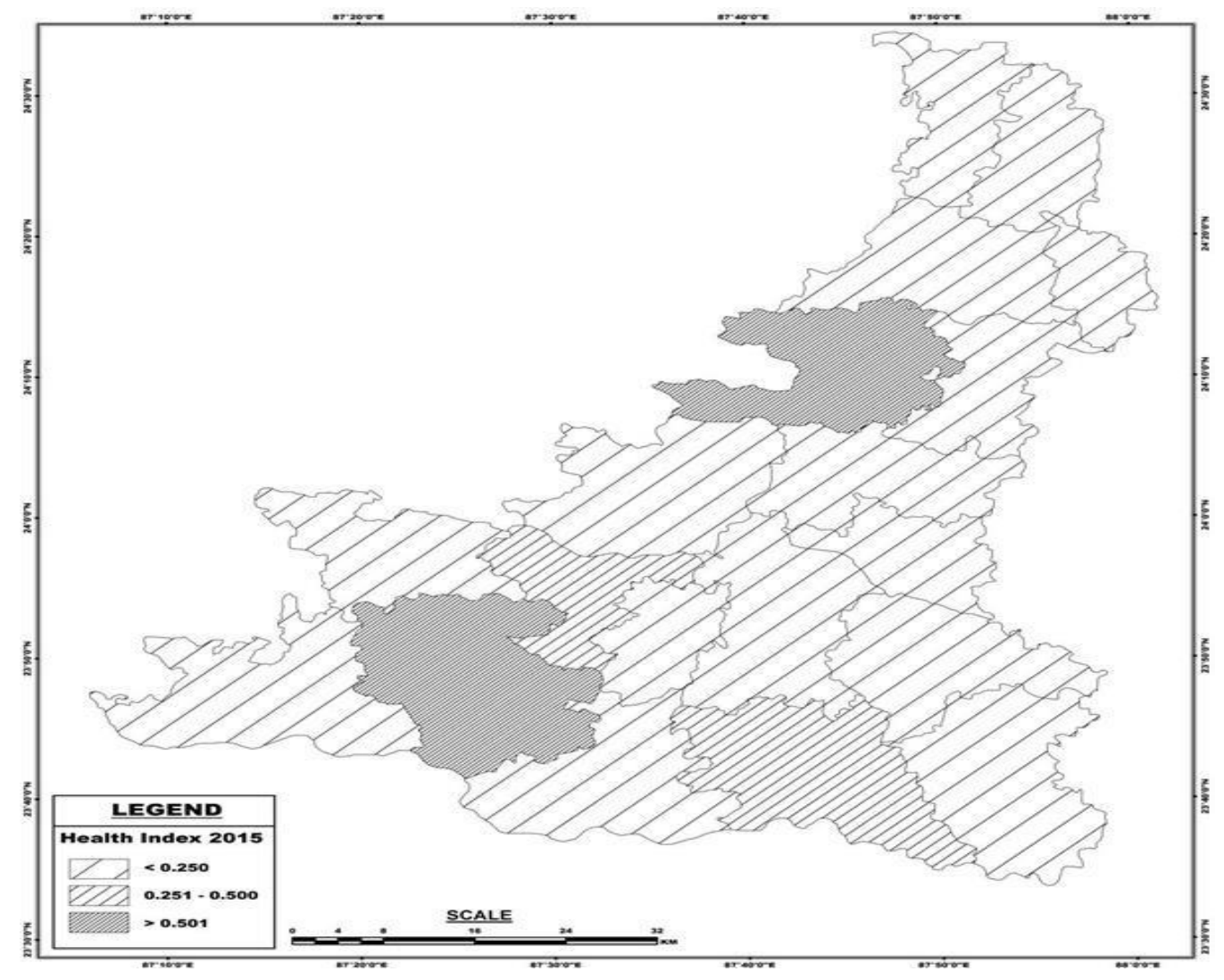


From the fig. no. 5 overall Health Index determined for different blocks of Birbhum district is very poor. According to Health index of 2011 the blocks of Birbhum District can be divided into three categories:

1. Less developed Blocks: Blocks with index value below 0.250 are 'less developed.' Among 19 blocks 15 blocks are in the lowest level of health index. There are Nalhati-I, Nalhati-II, Murarai-I, Murarai-II, Mayureswar-I, Mayureswar-II, Rampurhat-II, Mohammad Bazar, Sainthia, Rajnagar, Suri-II, Khoyrasole, Labhpur, Nanoor, Illambazar.

2. Moderately Developed Blocks: Blocks with index value between 0.251-0.500 are 'Moderately Developed Blocks.' Bolpur-Sriniketan and Suri I have the moderate level of health Index.

3. Developed Blocks: Blocks with index value 0.501 are 'developed.' Only Dubrajpur and Rampurhat I lie in this group.

In various blocks of Birbhum district public health care infrastructure consists of 1 district hospital located at the district headquarter, 2 Sub-divisional hospitals situated in 2 subdivisions, 4 Rural Hospitals $(\mathrm{RH})$ which are better equipped than the BPHCs and located at block headquarters, 15 Block Primary Health Centres (BPHCs) located at the headquarters of the Blocks and 58 Primary Health Centers (PHCs). So the headquarters are getting more facilities than the rest of the district. These health infrastructures should be decentralized.

\section{Conclusion}

The recent scenario of health infrastructure is highly un-satisfactory. The presence of health personnel is often much less than required by the prescribed norms. The health plan must be based on the needs and demands of the target group and the constraints of resources. The new health policy 2002 and the national health policy 2017 are trying to mitigate the problems. The period of policy should be more frequent so that the problems can be monitored quickly. In the policy priority should be given to the quality services and more accessible health institutions in rural areas The District is a poor performer in the health dimension. The accessibility of health care facilities is very poor in the study area. Disparities in health care facilities are found among the blocks of the districts and also from rural area to urban area of the district. But over the years the district has seen improvement in the health index. In 2009 health index of Birbhum district varies from 0.02 to 0.10 (Roy, Debasish, 2013) whereas in 2015 it is slightly higher i.e. from 0.30 to 2.30 . It is vital to address gaps between what exists and what is desired. Clinical services are to be provided in underserved areas and mobile clinics can be arranged in remote places. The Government of India spends only 1.60 percent of its GDP as public expenditure on health according to the budget estimate for the year 2020. This is very low compared to other countries. The United States spends the most i.e. 18 percent of its GDP on public health. More money should be spent on public health care because the healthy people are the valuable asset of our society.

\section{References}

1. District Statistical Handbook, 2011, Govt. of W.B., Bureau of applied economics \& statistics, Dept. Of planning, statistics \& programme monitoring, pp-18-19

2. Prasad, Neeta February, (2010). Chief editor of Kurukshetra, A Journal of Rural Development, Vol.58,No.4,p-2

3. Misra, R.P. (2007). Geography of health, concept publishing company, New Delhi. pp 433- 447

4. Roy, Debasish (2013) status of human development in the district of Birbhum at block level in Sociology and Anthropology 1(2). 104-110, 2013, Horizon Research Publishing. Pp-104- 106 ,http://www.hrpub.org DOI: 10.13189/sa.2013.010209

5. Status of Rural Health Care And The Hidden Disparity: A Study Of Birbhum District, West Bengal, www.iosrjournals.org 14

6. Wbplan.gov.in, DHDR_Birbhum, chatper - 3 Health and health care in Human Development Report Birbhum page $-39-41$

7. www.isca.in 
Annexure 01

\begin{tabular}{|c|c|c|c|c|c|c|c|c|c|c|c|}
\hline$\#$. & $\begin{array}{l}\text { Name of the Blocks } \\
\text { of Birbhum District }\end{array}$ & $\begin{array}{c}\text { No. of } \\
\text { Hospitals }\end{array}$ & $\begin{array}{c}\text { No. of } \\
\text { Rural } \\
\text { Hospitals }\end{array}$ & $\begin{array}{l}\text { Block primary } \\
\text { Health } \\
\text { Centres }\end{array}$ & $\begin{array}{l}\text { Primary } \\
\text { health } \\
\text { Centres }\end{array}$ & $\begin{array}{l}\text { Other dept. of } \\
\text { govt. of WB } \\
\text { Including state } \\
\text { govt. undertaking }\end{array}$ & $\begin{array}{c}\text { Govt. of India } \\
\text { including central } \\
\text { govt. undertaking }\end{array}$ & $\begin{array}{l}\text { N.G.O. } \\
\text { /Private } \\
\text { bodies }\end{array}$ & Total & $\begin{array}{l}\text { Total } \\
\text { no. of } \\
\text { beds }\end{array}$ & $\begin{array}{l}\text { Total no. } \\
\text { of Doctors }\end{array}$ \\
\hline 1. & Nalhati I & & 1 & 0 & 3 & & & 1 & 5 & 71 & 4 \\
\hline 2. & Nalhati li & & 0 & 1 & 2 & & & 0 & 3 & 31 & 3 \\
\hline 3. & Murarai I & & 1 & 0 & 2 & & & 0 & 3 & 83 & 5 \\
\hline 4. & Murarai li & & 1 & 0 & 4 & & & 0 & 5 & 52 & 8 \\
\hline 5. & Mayureswar I & & 1 & 0 & 2 & & & 0 & 3 & 31 & 6 \\
\hline 6. & Mayureswar li & & 1 & 0 & 3 & & & 0 & 4 & 52 & 6 \\
\hline 7. & Rampurhat I & 1 & 0 & 1 & 4 & & 1 & 1 & 7 & 355 & 33 \\
\hline 8. & Rampurhat li & & 1 & 0 & 3 & & & 0 & 4 & 60 & 5 \\
\hline 9. & Mahammad Bazar & & 1 & 0 & 4 & 1 & & 0 & 6 & 64 & 7 \\
\hline 10. & Saithia & & 1 & 0 & 5 & & & 0 & 5 & 47 & 5 \\
\hline 11. & Dubrajpur & 1 & 1 & 0 & 4 & & & 1 & 7 & 368 & 8 \\
\hline 12. & Rajnagar & & 1 & 0 & 2 & & & 0 & 3 & 31 & 6 \\
\hline 13. & Siuri I & 1 & 0 & 1 & 2 & 2 & & 1 & 4 & 80 & 4 \\
\hline 14. & Siuri li & & 1 & 0 & 2 & & & 0 & 3 & 31 & 3 \\
\hline 15. & Khoyrasol & & 1 & 0 & 3 & & & 0 & 4 & 37 & 5 \\
\hline 16. & Bolpur- Sriniketan & 1 & & 1 & 3 & & 1 & 6 & 11 & 310 & 26 \\
\hline 17. & Labpur & & 1 & 0 & 5 & & & 0 & 6 & 64 & 7 \\
\hline 18. & Nanoor & & 1 & 0 & 3 & & & 1 & 5 & 48 & 7 \\
\hline 19. & Illambazar & & 1 & 0 & 2 & & & 1 & 4 & 64 & 6 \\
\hline & Total & 4 & 15 & 4 & 58 & 3 & 2 & 12 & 92 & 1879 & 154 \\
\hline
\end{tabular}

Source: District Statistical Handbook, 2011 (Birbhum) 
Annexure 02

\begin{tabular}{|c|c|c|c|c|c|c|c|c|}
\hline$\#$ & Name of the Blocks & Area in sq. km. & Total & $\begin{array}{l}\text { Health Centres } \\
\text { /10 sq. km. }\end{array}$ & \begin{tabular}{|c|} 
No. of beds \\
$/ 1000$ populations
\end{tabular} & $\begin{array}{r}\text { No. of doctors } \\
/ 1000 \text { populations }\end{array}$ & $\begin{array}{c}\text { No. of family welfare } \\
\text { Centres } / 1000 \text { populations }\end{array}$ & $\begin{array}{c}\text { Health } \\
\text { Index, } 2011\end{array}$ \\
\hline 1. & Nalhati I & 249.71 & 5 & 0.2002 & 0.3466 & 0.0195 & 0.0049 & 0.5713 \\
\hline 2. & Nalhati li & 109.15 & 3 & 0.2749 & 0.2426 & 0.0235 & 0.0078 & 0.5487 \\
\hline 3. & Murarai I & 175.51 & 3 & 0.1709 & 0.4350 & 0.0262 & 0.0052 & 0.6374 \\
\hline 4. & Murarai li & 185.33 & 5 & 0.2698 & 0.2342 & 0.0360 & 0.0045 & 0.5445 \\
\hline 5. & Mayureswa R I & 224.83 & 3 & 0.1334 & 0.1940 & 0.0376 & 0.0063 & 0.3713 \\
\hline 6. & Mayureswa R li & 156.57 & 4 & 0.2555 & 0.4073 & 0.0470 & 0.0078 & 0.7176 \\
\hline 7. & Rampurhat I & 287.63 & 7 & 0.2434 & 1.8839 & 0.1751 & 0.0053 & 2.3077 \\
\hline 8. & Rampurhat li & 181.55 & 4 & 0.2203 & 0.3194 & 0.0266 & 0.0053 & 0.5717 \\
\hline 9. & Mahammad Bazar & 315.64 & 6 & 0.1901 & 0.3889 & 0.0425 & 0.0061 & 0.6276 \\
\hline 10. & Saithia & 304.39 & 5 & 0.1643 & 0.2406 & 0.0256 & 0.0051 & 0.4356 \\
\hline 11. & Dubrajpur & 344.88 & 7 & 0.2030 & 2.0283 & 0.0441 & 0.0055 & 2.2808 \\
\hline 12. & Rajnagar & 221.47 & 3 & 0.1355 & 0.3975 & 0.0769 & 0.0128 & 0.6228 \\
\hline 13. & Siuri I & 154.65 & 4 & 0.2586 & 0.7183 & 0.0359 & 0.0090 & 1.0218 \\
\hline 14. & Siuri li & 135.81 & 3 & 0.2209 & 0.3547 & 0.0343 & 0.0114 & 0.6213 \\
\hline 15. & Khoyrasol & 272.19 & 4 & 0.1470 & 0.2414 & 0.0326 & 0.0065 & 0.4275 \\
\hline 16. & Bolpur-Sriniketan & 334.58 & 11 & 0.3288 & 1.5305 & 0.1284 & 0.0049 & 1.9925 \\
\hline 17. & Labpur & 267.98 & 6 & 0.2239 & 0.3170 & 0.0347 & 0.0050 & 0.5805 \\
\hline 18. & Nanoor & 311.83 & 5 & 0.1603 & 0.2195 & 0.0320 & 0.0046 & 0.4165 \\
\hline 19. & Illambazar & 261.54 & 4 & 0.1529 & 0.3794 & 0.0356 & 0.0059 & 0.5738 \\
\hline
\end{tabular}

